\title{
Assessing Air Quality in Dhaka City
}

\author{
Mohammad Abdul Motalib ${ }^{1 *}$, Rodel D. Lasco ${ }^{2,3}$ \\ ${ }^{1}$ Department of Environment, Dhaka, Bangladesh \\ ${ }^{2}$ World Agroforestry Centre, Khush Hall, International Rice Research Institute, Los Baños, Laguna, Philippines \\ ${ }^{3}$ School of Environmental Science and Management, University of the Philippines Los Baños, College, Laguna, Philippines
}

\begin{abstract}
This study assessed the main factors that affect the city's air pollution levels in Dhaka. Among the variables analyzed, specifically $\mathrm{PM}_{10}, \mathrm{PM}_{2.5}, \mathrm{SOx}, \mathrm{NOx}, \mathrm{NO}_{2}, \mathrm{CO}$ and $\mathrm{O}_{3}$, only $\mathrm{PM}_{10}$ and PM $\mathrm{P}_{2.5}$ exceeded the Bangladesh air quality standards and World Health Organization air quality guidelines. Based on the air pollution level of Dhaka City, $\mathrm{SO}_{2}, \mathrm{NO}_{2}, \mathrm{CO}_{2}$, and $\mathrm{O}_{3}$ are not exited the air quality standards, and only $\mathrm{PM}_{10}$ and $\mathrm{PM}_{2.5}$ are polluted Level.
\end{abstract}

Keywords: Dhaka City, air quality, air pollution, air quality standard

\section{Introduction}

Dhaka, the capital city of Bangladesh, comprises the Dhaka City Corporation (DCC) and five adjacent municipal areas, Savar, Narayanganj, Gazipur, Keraniganj, and Tongi. The area of this mega city is $1,353 \mathrm{~km}^{2}$, of which DCC occupies $276 \mathrm{~km}^{2}$. Air pollution in Dhaka City is reported to be serious and damaging to public health. In the winter of 1996-97, air pollution in the city became severest when lead in the air was reported higher than in the atmosphere of any other place of the world [1]. Unfortunately, motor vehicles and brick kilns are the largest sources of particulate air pollution including black carbon in Dhaka [2]. The air pollution of Dhaka comes from different types of brick kilns those are located in different zones of Dhaka [3].

The earlier governmental interventions, the contribution from the motor vehicles has decreased over the years, and the contributions from the brick industries have become more prominent. The number of brick kilns operating around Dhaka has increased significantly in recent years. Until now, the majority of the brick factories are using Fixed Chimney Kiln (FCK) technology with coal as the primary fuel since it is cheaper than alternatives [4]. FCKs are not energy efficient and thus emissions are relatively high. To reduce the emissions from the brick sector, the government is working to introduce modification in FCK technology and newer technology such as Zigzag and Hybrid Hoffman kilns, which are more energy efficient [4]. Brickfields have been identified as a vital pollutant source of the main cities of the country. At present, the air quality in Dhaka City is severely affected by the pollutants from hundreds of brickfields located at the entrance points into the city, which are Amin Bazar, Keraniganj, Fatulla, Pagla, Tongi, Ashulia [5]. Verification of the applicability of an effective air quality model for Bangladesh conditions, especially for brickfield pollution was the main concern. Particulate matter had been identified as the most significant pollutant in that region which should be addressed immediately [1].

Dust due to there-suspension on roads, which is an indirect source of motor vehicle activity, is a major cause of air pollution (in the coarse mode of PM), due to lack of sufficient infrastructure (paved roads) to support the growing fleets and congestion. The clusters of brick kilns lying north of Dhaka contribute $\sim 40$ percent of the measured fine PM pollution. Growing construction activity (also contributing to the fugitive dust) is leading the demand for brick kilns and burning of biomass and low quality coal is result to pollution [6].

These receptor modeling studies estimated an average contribution of $30-40 \%$ originating from brick kilns to total ambient $\mathrm{PM}_{2.5}$ pollution. Simulations using CMAQ chemical transport dispersion modeling system over Dhaka and Bangladesh, estimated at least 35\% of ambient $\mathrm{PM}_{10}$ and at least $15 \%$ of the ambient $\mathrm{PM}_{2.5}$ in DMA is associated with brick kiln emissions [7].

Air pollution has become one of the serious environmental concerns in urban areas, particularly on the adverse health effects that have been associated with ambient fine particles [8] [9]. Due to enhanced human activities producing increased emissions, atmospheric pollution in urban area has become a major issue in many developing countries all over the world. The rates of increase in pollutant concentrations in the cities of the developing countries are higher than those of the developed countries [10].

The costs and benefits of environmental policies aims at reducing air pollution and provide policy recommendations in order to better address environmental health issues [11]. In general, the study aimed to do analyze the factors that cause air pollution in Dhaka, Bangladesh. Specifically, the study aimed to; identify and determine the significance of the existing air pollution condition in Dhaka, Bangladesh.

\section{Material and Methods}

Since April 2002, the DoE has managed a continuous air monitoring station (CAMS) in the Shangshad Bhaban premises. The facility is capable of monitoring all criteria pollutants, except lead. Air pollution data on $\mathrm{PM}_{10}, \mathrm{PM}_{2.5}$, $\mathrm{NO}_{2}, \mathrm{NO}_{\mathrm{x}}, \mathrm{SO}_{\mathrm{x}}, \mathrm{CO}$, and $\mathrm{O}_{3}$ levels were collected from CAMS. Threshold levels were obtained from the [12] and [13]. The Statistical Analysis Software (SAS) was used to determine significant levels of air pollution in Dhaka City. Air pollution data on factors such as $\mathrm{PM}_{10}, \mathrm{PM}_{2.5}, \mathrm{NO}_{2}$, $\mathrm{NO}_{\mathrm{x}}, \mathrm{SO}_{\mathrm{x}}, \mathrm{CO}$, and $\mathrm{O}_{3}$ were assessed and the most

\section{Volume 4 Issue 12, December 2015}




\section{International Journal of Science and Research (IJSR) \\ ISSN (Online): 2319-7064}

Index Copernicus Value (2013): 6.14 | Impact Factor (2014): 5.611

significant ones identified in accordance to government and WHO guidelines.

\section{Result}

In Dhaka, PM is the air pollutant that is most harmful to public health and the environment as compared with other measured criteria pollutants. Among the group of air pollutants, PM is thought to be the most important with respect to health effects and reduced urban visibility. The major sources of PM in Dhaka are diesel-powered vehicles, two strokes engine gasoline vehicles, and brick kilns [14].

This study explored the condition of air pollution condition in Dhaka City, as well as the acceptable kilns policy on the surrounding brick kilns in the City. Data on air pollution in Dhaka City recorded that the yearly average of $\mathrm{PM}_{10}$ and $\mathrm{PM}_{2.5}$ is significantly high. The mean values are greater than that in Bangladesh and as compared with the air quality standard of WHO. The pollution level of $\mathrm{PM}_{10}$ and $\mathrm{PM}_{2.5}$ is highly significant, and indicates high pollution in Dhaka. By contrast, the analysis of other pollutants, such as $\mathrm{SOx}, \mathrm{NOx}, \mathrm{SO}_{2}, \mathrm{CO}$, and $\mathrm{O}_{3}$, indicated a low annual average; wherein mean values are less than that of Bangladesh's government and with the air quality standards specified by WHO. $\mathrm{PM}_{10}$ and $\mathrm{PM}_{2.5}$ values were higher than the 24-h average Bangladesh national ambient air quality standard [15].

Table 1 shows the test on equality of $\mathrm{PM}_{2.5}$ on annually threshold $(15 \mu \mathrm{g} / \mathrm{m} 3)$ set by the Bangladesh Government Air Quality Standard. The mean $\mathrm{PM}_{2.5}$ from 2002 to 2010 ranges from 62.75 to $89.5 \mu \mathrm{g} / \mathrm{m} 3$. The test processes that were used are t-test and sign-test. T-test needs the normality of the data set to be satisfied, while, sign-test can be used when the normality is not satisfied. Based on the test, Dhaka had means $\mathrm{PM}_{2.5}$ greater than the set threshold of the Bangladesh government from 2002 to 2010. This implies that Dhaka was air-polluted with $\mathrm{PM}_{2.5}$ in those years. The $\mathrm{PM}_{2.5}$ pollution level was analyzed based on WHO air quality threshold level. It was found that the mean of $\mathrm{PM}_{2.5}$ from year 2002 to 2010 ranged from 62.75 to $89.5 \mu \mathrm{g} / \mathrm{m} 3$. Both t-test and sign-test were used. Based on the tests, Dhaka had $\mathrm{PM}_{2.5}$ means greater than the set threshold of WHO from 2002 to 2010 (Table 2). This implies that Dhaka was air-polluted with $\mathrm{PM}_{2.5}$ in those years. Table 2 presents the summary of results. Tables 1 and 2 proved that the threshold level assessed by the Bangladesh government and WHO was reached by $\mathrm{PM}_{2.5}$. Therefore, the $\mathrm{PM}_{2.5}$ level of Dhaka is immensely polluted.

Table 1: Test on equality of $\mathrm{PM}_{2.5}$ on annual threshold $(15 \mu \mathrm{g} / \mathrm{m} 3)$ set by Bangladesh Government Air Quality standard

\begin{tabular}{|c|c|c|c|c|c|c|c|}
\hline Year & Mean & Standard Deviation & Normality & Test Procedure & $\begin{array}{c}\text { Test } \\
\text { Statistics }\end{array}$ & P-Value & Conclusion \\
\hline 2002 & 69.11 & 59.31 & not normal & sign-test & 4.5 & 0.0039 & $>$ than 15 \\
\hline 2003 & 77.25 & 58.52 & Normal & t-test & 3.684 & 0.0036 & $>$ than 15 \\
\hline 2004 & 78.25 & 45.22 & Normal & t-test & 4.844 & 0.0005 & $>$ than 15 \\
\hline 2005 & 85.25 & 57.09 & Normal & t-test & 4.262 & 0.0013 & $>$ than 15 \\
\hline 2006 & 75.66 & 55.78 & not normal & sign-test & 6 & 0.0005 & $>$ than 15 \\
\hline 2007 & 75.66 & 46.61 & not normal & sign-test & 6 & 0.0005 & $>$ than 15 \\
\hline 2008 & 74.5 & 48.40 & Normal & t-test & 4.258 & 0.0013 & $>$ than 15 \\
\hline 2009 & 89.5 & 59.57 & not normal & sign-test & 6 & 0.0005 & $>$ than 15 \\
\hline 2010 & 83.91 & 65.67 & Normal & t-test & 2.776 & 0.0321 & $>$ than 15 \\
\hline
\end{tabular}

Table 2: Test on equality of $\mathrm{PM}_{2.5}$ on annual threshold $(10 \mu \mathrm{g} / \mathrm{m} 3)$ set by WHO Air Quality Guidelines

\begin{tabular}{|c|c|c|c|c|c|c|c|}
\hline Year & Mean & Standard Deviation & Normality & Test Procedure & Test Statistics & $P$-Value & Conclusion \\
\hline 2002 & 69.11 & 59.31 & not normal & sign-test & 4.5 & 0.0039 & $>$ than 10 \\
\hline 2003 & 77.25 & 58.52 & normal & t-test & 3.980 & 0.0022 & $>$ than 10 \\
\hline 2004 & 78.25 & 45.22 & normal & t-test & 5.227 & 0.0003 & $>$ than 10 \\
\hline 2005 & 85.25 & 57.09 & normal & t-test & 4.565 & 0.0008 & $>$ than 10 \\
\hline 2006 & 75.66 & 55.78 & not normal & sign-test & 6 & 0.0005 & $>$ than 10 \\
\hline 2007 & 75.66 & 46.61 & not normal & sign-test & 6 & 0.0005 & $>$ than 10 \\
\hline 2008 & 74.5 & 48.40 & normal & t-test & 4.616 & 0.0007 & $>$ than 10 \\
\hline 2009 & 89.5 & 59.57 & not normal & sign-test & 6 & 0.0005 & $>$ than 10 \\
\hline 2010 & 83.91 & 65.67 & normal & t-test & 2.977 & 0.0247 & $>$ than 10 \\
\hline
\end{tabular}

Table 3 shows the test on equality of $\mathrm{PM}_{10}$ on annual threshold $50(\mu \mathrm{g} / \mathrm{m} 3)$ set by the Bangladesh Government Air Quality Guidelines. The mean $\mathrm{PM}_{10}$ from 2002 to 2010 ranged from 110.66 to $147.34 \mu \mathrm{g} / \mathrm{m} 3$. Both t-test and signtest were used. Based on the tests, Dhaka had greater $\mathrm{PM}_{10}$ means than the set threshold of the Bangladesh Government Air Quality Standard from 2002 to 2010. This implies that Dhaka was air-polluted with $\mathrm{PM}_{10}$ in those years. Table 4 presents the test on equality of $\mathrm{PM}_{10}$ on

\section{Volume 4 Issue 12, December 2015}




\section{International Journal of Science and Research (IJSR) \\ ISSN (Online): 2319-7064}

Index Copernicus Value (2013): 6.14 | Impact Factor (2014): 5.611

annual threshold $(20 \mu \mathrm{g} / \mathrm{m} 3)$ set by the WHO Air Quality Guidelines.

The mean $\mathrm{PM}_{10}$ ranged from 110.66 to $147.34 \mu \mathrm{g} / \mathrm{m} 3$ from 2002 to 2010. Both t-test and sign-test were used. Based on the tests, Dhaka had greater $\mathrm{PM}_{10}$ means than the set threshold of the WHO Air Quality Standard from 2002 to
2010. This implies that Dhaka was air-polluted with $\mathrm{PM}_{10}$ in those years. Tables 3 and 4 proved that the threshold level assessed by the Bangladesh government and WHO was exceeded by PM. Therefore, the $\mathrm{PM}_{10}$ level implies that Dhaka is immensely polluted.

Table 3: Test on equality of $\mathrm{PM}_{10}$ on annual threshold $(50 \mu \mathrm{g} / \mathrm{m} 3)$ set by Bangladesh Government Air Quality Standard

\begin{tabular}{|c|c|c|c|c|c|c|c|}
\hline Year & Mean & Standard Deviation & Normality & Test Procedure & Test Statistics & $P$-Value & Conclusion \\
\hline 2002 & 110.66 & 62.79 & not normal & sign-test & 4.5 & 0.0039 & $>$ than 50 \\
\hline 2003 & 134.58 & 79.26 & normal & t-test & 3.696 & 0.0035 & $>$ than 50 \\
\hline 2004 & 132.33 & 70.08 & normal & t-test & 4.069 & 0.0019 & $>$ than 50 \\
\hline 2005 & 129.41 & 71.76 & normal & t-test & 3.833 & 0.0028 & $>$ than 50 \\
\hline 2006 & 117.83 & 69.64 & normal & t-test & 3.374 & 0.0062 & $>$ than 50 \\
\hline 2007 & 126.41 & 72.08 & normal & t-test & 3.672 & 0.0037 & $>$ than 50 \\
\hline 2008 & 122.25 & 66.64 & normal & t-test & 3.755 & 0.0032 & $>$ than 50 \\
\hline 2009 & 143.58 & 80.94 & normal & t-test & 4.005 & 0.0021 & $>$ than 50 \\
\hline 2010 & 147.34 & 86.19 & normal & t-test & 2.987 & 0.0244 & $>$ than 50 \\
\hline
\end{tabular}

Table 4: Test on equality of $\mathrm{PM}_{10}$ on annual threshold $(20 \mu \mathrm{g} / \mathrm{m} 3)$ set by WHO Air Quality Guidelines

\begin{tabular}{|c|c|c|c|c|c|c|c|}
\hline Year & Mean & Standard Deviation & $\begin{array}{c}\text { Norma- } \\
\text { Lity }\end{array}$ & Test Procedure & Test Statistics & $P$-Value & Conclusion \\
\hline 2002 & 110.66 & 62.79 & not normal & sign-test & 4.5 & 0.0039 & $>$ than 20 \\
\hline 2003 & 134.58 & 79.26 & normal & t-test & 5.007 & 0.0004 & $>$ than 20 \\
\hline 2004 & 132.33 & 70.08 & normal & t-test & 5.552 & 0.0002 & $>$ than 20 \\
\hline 2005 & 129.41 & 71.76 & normal & t-test & 5.281 & 0.0003 & $>$ than 20 \\
\hline 2006 & 117.83 & 69.64 & normal & t-test & 4.866 & 0.0005 & $>$ than 20 \\
\hline 2007 & 126.41 & 72.08 & normal & t-test & 5.113 & 0.0003 & $>$ than 20 \\
\hline 2008 & 122.25 & 66.64 & normal & t-test & 5.314 & 0.0002 & $>$ than 20 \\
\hline 2009 & 143.58 & 80.94 & normal & t-test & 5.289 & 0.0003 & $>$ than 20 \\
\hline 2010 & 147.34 & 86.19 & normal & t-test & 3.908 & 0.0079 & $>$ than 20 \\
\hline
\end{tabular}

Yearly Pair-wise Comparison of $\mathrm{PM}_{10}$ and $\mathrm{PM}_{2.5}$

Pair-wise comparison of the $\mathrm{PM}_{10}$ means from 2002 to 2010 using the related case. T-test using the related case or sign test can be used for testing the pair-wise comparison. T-test using related case still needs the normality assumption, while sign test can be used if the assumption is not satisfied. There were 36 pair-wise comparisons, only six of which were found to be significant. The mean $\mathrm{PM}_{10}$ of 2003 was greater than 2006 as well as 2004 against 2007. This means that from 2003 to 2007 , mean $\mathrm{PM}_{10}$ was decreasing in trend. On the other hand, mean $\mathrm{PM}_{10}$ in 2006 and 2008 were found to be less in 2010. Moreover, mean $\mathrm{PM}_{10}$ of 2007 and 2008 were less in 2009 based on the tests. This implies that the mean $\mathrm{PM}_{10}$ was increasing from 2006 to 2010. Pair-wise comparison of the $\mathrm{PM}_{2.5}$ means from 2002 to 2010 using the related case. T-test using the related case or sign test can be used for testing the pairwise comparison. Among the 36 pair-wise comparisons, only two were found to be significant. $\mathrm{PM}_{2.5}$ of 2007 and 2008 were less in 2009 based on the tests. This implies that the mean $\mathrm{PM}_{10}$ was increasing from 2007 to 2009.
NO $_{x}$ Assessment on 24-hour Threshold Level Set by Bangladesh Government

$\mathrm{NO}_{\mathrm{x}}$ are emitted especially from high temperature combustion and are produced naturally during thunderstorms by electrical discharge. Nitrogen dioxide is a chemical compound with the formula $\mathrm{NO}_{2}$. It is one of the several nitrogen oxides. This reddish-brown toxic gas has a sharp, biting odor. $\mathrm{NO}_{2}$ is one of the most prominent air pollutants. The $\mathrm{NO}_{\mathrm{X}}$ threshold level was $53 \mathrm{ppb}$ based on the Bangladesh Air Quality Standard. The mean $\mathrm{NO}_{\mathrm{X}}$ from 2002 to 2005 ranged from 37.5 to 59.5 . The test procedures used were t-test and sign-test. The values from the test had mean $\mathrm{NO}_{\mathrm{X}}$ equal to threshold level of Bangladesh Government from 2002 to 2005. This implies that Dhaka air was not polluted with $\mathrm{NO}_{\mathrm{X}}$ in those years. $\mathrm{NO}_{2}$ Assessment on 24-hour Threshold Level Set by WHO Air Quality Guidelines.

The $\mathrm{NO}_{2}$ threshold level was $21.27 \mathrm{ppb}$ based on the WHO Air Quality Guidelines. The mean $\mathrm{NO}_{2}$ ranged from 22.5 to 37.96 from 2002 to 2005 . T-test and sign-test were used in testing the equality to the threshold set by WHO. The values from the test had mean $\mathrm{NO}_{2}$ equal to threshold level of WHO from 2002 to 2005. This implies that Dhaka was not air-polluted with $\mathrm{NO}_{2}$ in those years.

\section{Volume 4 Issue 12, December 2015}




\section{International Journal of Science and Research (IJSR) \\ ISSN (Online): 2319-7064}

Index Copernicus Value (2013): 6.14 | Impact Factor (2014): 5.611

SO $_{x}$ Pollution Assessment on Annual Threshold Set by Bangladesh Government and WHO Air Quality Guidelines

Sulfur oxides $\left(\mathrm{SO}_{\mathrm{x}}\right)$, especially sulfur dioxide, are a chemical compound with the formula $\mathrm{SO}_{\mathrm{X}} \cdot \mathrm{SO}_{\mathrm{X}}$ is produced by volcanoes and in various industrial processes. Since coal and petroleum often contain sulfur compounds, their combustion generates sulfur dioxide. Further oxidation of $\mathrm{SO}_{\mathrm{X}}$, usually in the presence of a catalyst, such as $\mathrm{NO}_{2}$, forms $\mathrm{H}_{2} \mathrm{SO}_{4}$, and thus produces acid rain.

The $\mathrm{SO}_{\mathrm{X}}$ threshold level was $30 \mathrm{ppb}$ based on the Bangladesh Air Quality Standard and 7.634 ppb bases on the WHO Air Quality Guidelines. The mean $\mathrm{SO}_{\mathrm{X}}$ ranged from 5.99 to 8.16 from 2002 to 2006 . The test procedures used were t-test and sign-test. The values from the test had mean $\mathrm{SO}_{\mathrm{X}}$ less than the set threshold level of Bangladesh government in 2002 to 2006. This implies that Dhaka was not air-polluted with $\mathrm{SO}_{\mathrm{X}}$ in those years. T-test or sign-test was used in testing the equality to the threshold set by WHO. The values from the test had mean $\mathrm{SO}_{\mathrm{x}}$ equal to threshold level of WHO in 2002 to 2005. In this year, Dhaka had mean $\mathrm{SO}_{\mathrm{x}}$ less than threshold level of WHO. This implies that Dhaka was not air-polluted with $\mathrm{SO}_{\mathrm{x}}$ in those years.

\section{CO Assessment on Threshold Level Set by Bangladesh Government and WHO Air Quality Guidelines}

Carbon monoxide (CO) is a colorless, odorless, nonirritating but very poisonous gas. It is a product by incomplete combustion of fuel, such as natural gas, coal, or wood. Vehicular exhaust is a major source of $\mathrm{CO}$. Hourly average of $\mathrm{CO}$ standard is $35 \mathrm{ppm}$ as set by the Bangladesh government and $26.2 \mathrm{ppm}$ as set by WHO Air Quality Guidelines. The mean CO from 2002 to 2006 ranged from 0.72 to 1.5 . In testing the equality to the threshold set by Bangladesh Government, t-test and signtest were used. Dhaka had mean CO less than the set threshold level of Bangladesh Government in 2002 to 2006. The mean of $\mathrm{CO}$ from 2002 to 2006 ranged from 0.72 to 1.5 . In testing the equality to the threshold set by WHO Air Quality Guidelines, t-test or sign-test were used. Dhaka had mean CO less than the set threshold level of WHO Air Quality Guidelines in 20012 to 2006. This indicates that Dhaka was not polluted with $\mathrm{CO}$ in those years.

Ozone $\left(\mathrm{O}_{3}\right)$ Assessment on Threshold Level Set by Bangladesh Government and WHO Air Quality Guidelines

Ozone $\left(\mathrm{O}_{3}\right)$, or trioxide, is a triatomic molecule, consisting of three oxygen atoms. Ozone is a pale blue gas, slightly soluble in water, and much more soluble in inert non-polar solvents such as carbon tetrachloride. Cars and trucks, gas stations, and factories put the ingredients for ozone into the air every day. Even relatively low levels of ozone can cause health effects. People with lung disease, children, older adults, and people who are active outdoors may be particularly sensitive to ozone. Breathing ozone can trigger a variety of health problems including chest pain, coughing, throat irritation, and congestion. It can worsen bronchitis, emphysema, and asthma. Ground level ozone also can reduce lung function and inflame the linings of the lungs. The test on equality of $\mathrm{O}_{3}$ on 8-hour threshold (80 ppb) as set by Bangladesh Government Air Quality Guidelines and $50 \mathrm{ppb}$ based on the WHO Air Quality Guidelines. The mean $\mathrm{O}_{3}$ ranged from 24.39 to $35.52 \mathrm{ppb}$ from 2002 to 2008. The test procedures used were t-test and sign-test. Based on the tests, Dhaka had mean $\mathrm{O}_{3}$ less than the set threshold of Bangladesh Government in 2002 to 2008. The mean $\mathrm{O}_{3}$ ranged from 24.39 to $35.52 \mathrm{ppb}$ from 2002 to 2008. The test procedures used were t-test and sign-test. Dhaka had mean $\mathrm{O}_{3}$ less than the set threshold level of WHO in 2002 to 2006 . This implies that Dhaka was not air-polluted with $\mathrm{O}_{3}$ in those years.

\section{Discussion}

Comparing brick kilns' operating season and nonoperating season, $123 \mu / \mathrm{m}^{3}$ is the $\mathrm{PM}_{2.5}$ mean from November to April, while it is $35.4 \mu / \mathrm{m}^{3}$ from May to October. It is proven that brick kilns emissions are higher during operating season by $88 \mu / \mathrm{m}^{3}$. Nevertheless, both seasons are significant and exited the threshold level. Five months per year, brick kilns are the city's main source of fine particulate pollution [16]. Similarly, the annual mean of brick kilns $\mathrm{PM}_{10}$ from November to April is $118 \mu / \mathrm{m}^{3}$, which is higher than then on-operating season. Results show the variation of $\mathrm{PM}_{2.5}$ and $\mathrm{PM}_{10}$ mass concentrations of mean values in each season. The characteristic of seasonal variation was observed for $\mathrm{PM}_{10}$ as well as for the fine particles, with elevated concentrations during the brick production period. Therefore, PM level peaks were very high during brick-making seasons. Both variables were observed to be very high during the operating season than the non-operating season even considering brick production. Also $\mathrm{PM}_{2.5}, \mathrm{PM}_{10}$ and $\mathrm{BC}$ concentration levels at a receptor site largely depend on the meteorological conditions including rainfall, wind speed and wind direction [15].

This analysis also proved that in Dhaka City, $\mathrm{SO}_{2}, \mathrm{NO}_{2}$, $\mathrm{CO}_{2}$, and $\mathrm{O}_{3}$ was not exceeded the standards pollution level. Moreover, based on the air pollution level of Dhaka City, $\mathrm{SO}_{2}, \mathrm{NO}_{2}, \mathrm{CO}_{2}$, and $\mathrm{O}_{3}$ are not exceeded the standards, and only $\mathrm{PM}_{10}$ and $\mathrm{PM}_{2.5}$ are exceeded those standard and made the air polluted.

\section{Conclusion and Recommendation}

This study explored the condition of air pollution condition in Dhaka City, as well as the effects on human health of the surrounding brick kilns in Dhaka. Data on air pollution in Dhaka City recorded that the yearly average of $\mathrm{PM}_{10}$ and $\mathrm{PM}_{2.5}$ is significantly high. The mean values are greater than that in Bangladesh and as compared with the air quality standard of WHO. The pollution level of PM 10 and PM 2.5 is highly significant, and indicates high pollution in Dhaka. By contrast, the analysis of other pollutants, such as $\mathrm{SOx}, \mathrm{NOx}, \mathrm{SO}_{2}, \mathrm{CO}$, and $\mathrm{O}_{3}$, indicated a low annual average; mean values are less than that of Bangladesh's government and as compared with air quality standards specified by WHO. Therefore, such

\section{Volume 4 Issue 12, December 2015}




\section{International Journal of Science and Research (IJSR) \\ ISSN (Online): 2319-7064}

Index Copernicus Value (2013): 6.14 | Impact Factor (2014): 5.611

pollutants are insignificant and have not exceeded the pollution level. Moreover, based on the air pollution level of Dhaka City, $\mathrm{SO}_{2}, \mathrm{NO}_{2}, \mathrm{CO}_{2}$, and $\mathrm{O}_{3}$ are not exited the air quality standards, and only $\mathrm{PM}_{10}$ and $\mathrm{PM}_{2.5}$ are polluted.

\section{References}

[1] Ahmed S., Hossain, I. 2008. Applicability of air pollution modelling in a cluster of brickfields in Bangladesh. Chemical Engineering Research Bulletin 12, pp. 28-34.

[2] Begum, B.A., Biswas. S.K, and Hopke, P. K. 2010. Key issues in controlling air pollutants in Dhaka, Bangladesh. Atmospheric Environment. In press. Atmospheric Environment 45, 7705-7713.

[3] Motalib, M. A, Rodel D.L, Enrique P. P, and Carmelita M. R, Josefina T. D. 2015. Health Impact of Air Pollution on Dhaka City By Different Technologies Brick Kilns. International Journal of Technology Enhancements and Emerging Engineering Research, Vol 3, Issue 05, pp. 127-132.

[4] Hossain, I. 2008. Impact of Brick kiln pollution on Dhaka City. http://centers.iub.edu. bd/chpd/Pres_Sem_Ijaz Hossain_Aprl 17-08.pdf.

[5] BPPW (BANGLADESH PUBLIC POLICY WATCH). 2003. Dhaka city state environment report, The United Nations Environment Program (UNEP), 2005, published by Unnayan Onneshan -The Innovators.

[6] Guttikunda S. 2009. Impact Analysis of Brick Kilns on the Air Quality in Dhaka, Bangladesh 2009, SIMair Working Paper Series: 21-2009.

[7] Billah I. A., Mam, S., Chatani, and Sudo K., 2012, Simulation of urban and regional air pollution in Bangladesh. J Geophys Res 117: D07303.

[8] Dockery D.J. and Pope, C.A. 1994. Acute respiratory effects of particulate air pollution. Annual Review of Public Health 15, 107.

[9] Dockery, D.W., Speizer. F.E., Stram. D.O., Ware, J. H. Spengler. J.D, and Ferris, B.G. 1989. Effects of inhalable particles on respiratory health of children. American Review of Diseases 139, 134.

[10] Kato N., Ogawa Y., Koike T., Sakamoto, T.S., Sakamoto, and Group R. 1991. Analysis of the structure of energy consumption and the dynamics of emissions of atmospheric species related to the global change (SOx, NOx and CO2) in Asia. NISTEP Report no 21, 4th Policy-oriented Research Group, National Institute of Science and Technology Policy, Tokyo.

[11] Scapecchi, P. 2008. "The Health Costs of Inaction with Respect to Air Pollution", OECD Environment Working Papers, No.2,OECD Publishing. http://dx.doi.org/10.1787/ 241481086362.

[12] Bangladesh Government Air Quality Standards. 2005 Bangladesh National Ambient Air QualityStandards,http://www.caseoef.gov.bd/filezone/ feedback/Revision $\% 20$ of $\% 20$ National $\% 20$ Ambient $\%$ 20Air\%20Quality\%20Standard.pdf.

[13] World Health Organization (WHO). 2010. Preventing disease through healthy environments, Public Health and Environment, World Health Organization, 20
Avenue Appia, 1211 Geneva 27, Switzerland, http://www.who.int/ipcs/features/air_pollution.pdf.

[14] Begum, B.A., Hossain, A., Saroar, G., Biswas, S.K., Nasiruddin, M., Nahar, N., Chowdury, Z., Hopke, P.K., 2011. Sources of carbonaceous materials in the airborne particulate matter of Dhaka. Asian Journal of Atmospheric Environment (AJAE) 5, 237-246.

[15] Begum, B.A., Tazmin. A., Rabbani. K.A., Biswas S.K., and Nasiruddin, M. 2009. Investigation of sources of particulate matter from the Tajgaon industrial area, Dhaka. Journal of Bangladesh Academy of Sciences, 33, (1), 71-85.

[16] Croitoru, L. and Maria S. 2012. Benefits and Costs of the Informal Sector: The Case of Brick Kilns in Bangladesh Journal of Environmental Protection, 2012, 3, 476-484, doi:10.4236/jep.2012.36058 Published Online June 2012 (http://www.SciRP. org/journal/jep)

\section{Author Profile}

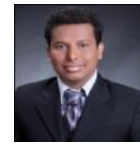

Mohammad Abdul Motalib received the PhD. Environmental Science program of University Philippines Los Baños (UPLB) in Philippines. He was granted a full Scholarship Program for the foreign Students of UP. He now with Senior Chemist at the Department of Environment (DoE) under the Ministry of Environment and Forests, Bangladesh. He previously worked as Lecturer in the Faculty of Chemistry at the Kalsindur College, Mymensingh, Bangladesh. 